\title{
Micropalaeontology of the hydrothermal region in the Guaymas Basin, Mexico
}

\author{
ADRIANA AYALA-LÓPEZ \\ Instituto de Ciencias del Mar y Limn., UNAM., Ciudad Universitaria, México D.F. 04510 Mexico. \\ Escuela Nacional Preparatoria, Plantel 8., UNAM., Mexico, D.F. Mexico. \\ ADOLFO MOLINA-CRUZ \\ Instituto de Ciencias del Mar y Limn., UNAM., Ciudad Universitaria, México D.F. 04510 Mexico.
}

\begin{abstract}
A micropalaeontological analysis of 40 sedimentary samples from a hydrothermal region in the Guaymas Basin, Gulf of California, Mexico, was carried out to describe microenvironments. These microenvironments were defined through a Q-mode Factor analysis of species abundance data from the benthic foraminiferal biocoenoses and thanatocoenoses. The benthic foraminiferal results were correlated with the biogeographic patterns of diatoms, radiolarians, planktonic foraminifers and ostracods through a 'graphic-multivariate analysis'. Although the microenvironments have a patchy distribution within the hydrothermal region, it is possible to define the following: (1) the 'hydrothermal environment', in which the benthic foraminifera Bulimina mexicana and Globocassidulina sp. cf. C. subglobosa coexist with the mollusc Calyptogena pacifica, even though the almost direct influence of the hydrothermal fluids drastically reduces the presence of the microfauna; (2) the 'bacterial environment', in which Trochammina sp. and Recurvoides sp. are associated with bacterial mats; and (3) the 'cool environment', further out from the direct hydrothermal influence. In this microenvironment the benthic foraminifera Bulimina spinosa, Bolivina seminuda and Cibicides sp. are common. These three benthic foraminiferal assemblages are different from other assemblages which live in the Guaymas Basin but are not influenced by hydrothermal fluids. In the non-hydrothermal regions, Uvigerina peregrina and Buliminella tenuata are common. The analysis of subsurface samples shows the same patterns as the superficial samples. $J$. Micropalaeontol. 13(2): 133-146, December 1994.
\end{abstract}

\section{INTRODUCTION}

Since the discovery of hydrothermal vents in the Galapagos Rift in 1977 (Ballard, 1984), numerous multidisciplinary studies have been carried out in different hydrothermal regions, in an attempt to describe and understand this phenomenon (Campbell \& Gieskes, 1984; Edmond, 1984; Grassle, 1984; Rau, 1985).

The hydrothermal region of the Guaymas Basin (Fig. 1), discovered in 1980 (Lonsdale et al., 1980), is marked by high sedimentation rates and high vertical and horizontal temperature gradients. Consequently, several geochemical and biological studies have been carried out in this region (Gieskes et al., 1982; Simoneit \& Lonsdale, 1982; Grassle, 1984, 1985). Molina-Cruz and Ayala-Lopez (1988) were the first to report on the influence of hydrothermal vents on the distribution of benthic foraminifera, but this study was based on a limited number of samples. Therefore, in order to improve our understanding of the factors that control the make up and distribution of benthic foraminiferal assemblages in a hydrothermal region, a new study was undertaken using a set of new samples, collected with the submersible DSRV 'Alvin' in the spring of 1988. The objectives of this investigation were: (a) to analyse the distribution and abundance of benthic foraminifera in 2 areas within the Guaymas Basin hydrothermal region, in the Southern Trough - 'Lutz Town' and 'Angel Rock' (Fig. 1); (b) to provide information about the transition from benthic foraminiferal biocoenoses to thanatocoenoses associated with the hydrothermal fluids; (c) to recognize and describe different microenvironments in the hydrothermal area using the distribution of benthic foraminiferal assemblages; (d) to analyse the local distribution of tests of other related groups, like planktonic foraminifers, radiolarians, diatoms and ostracods, in the sediments, to infer sedimentary features of these systems; and (e) to describe some aspects of the evolution of the dynamics of the hydrothermal vents.

To reach these objectives, the benthic foraminiferal biocoenoses and thanatocoenoses were analysed using two multivariate mathematical methods: Factor and Cluster Analysis (Kleinbaum et al., 1978; Buzas, 1979). These results were then correlated with the gross biogeography of diatoms, radiolaria, planktonic foraminifera and ostracods, through a 'graphic-multivariate analysis' (Molina-Cruz \& Martinez-Lopez, 1994).

\section{BACKGROUND}

The Guaymas Basin is part of a complex rift zone along the northern extension of the East Pacific Rise within the Gulf of California. The Guaymas Basin is an actively spreading oceanic basin and consists of two rift valleys: the Northern and Southern Troughs, separated by a $20 \mathrm{~km}$ transform fault area (Fig. 1a; Simoneit \& Lonsdale, 1982). 


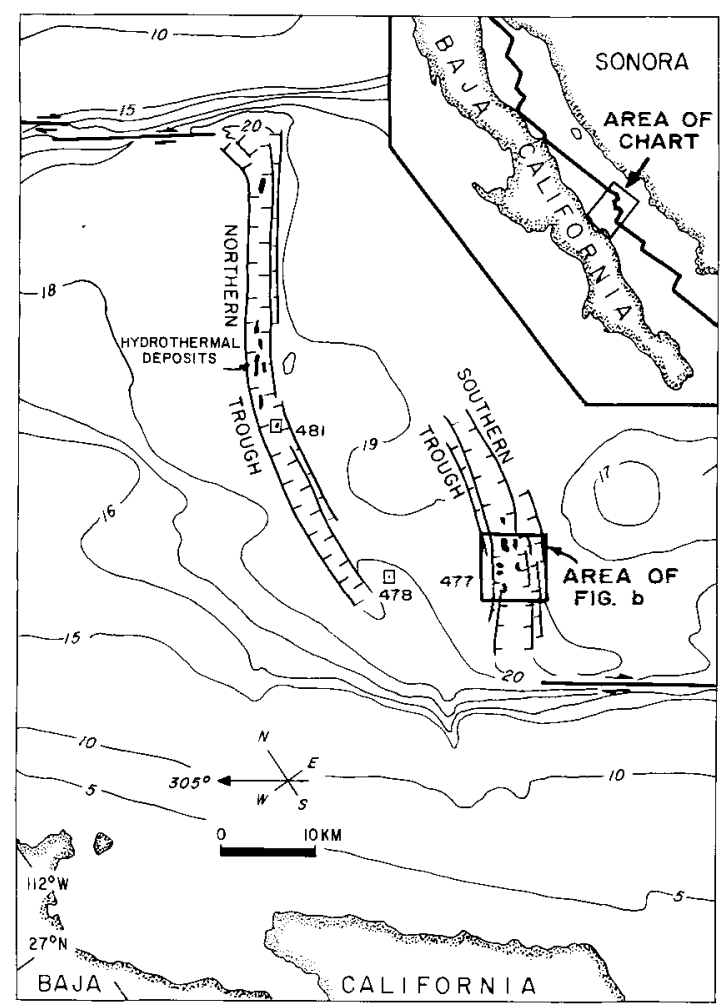

a)

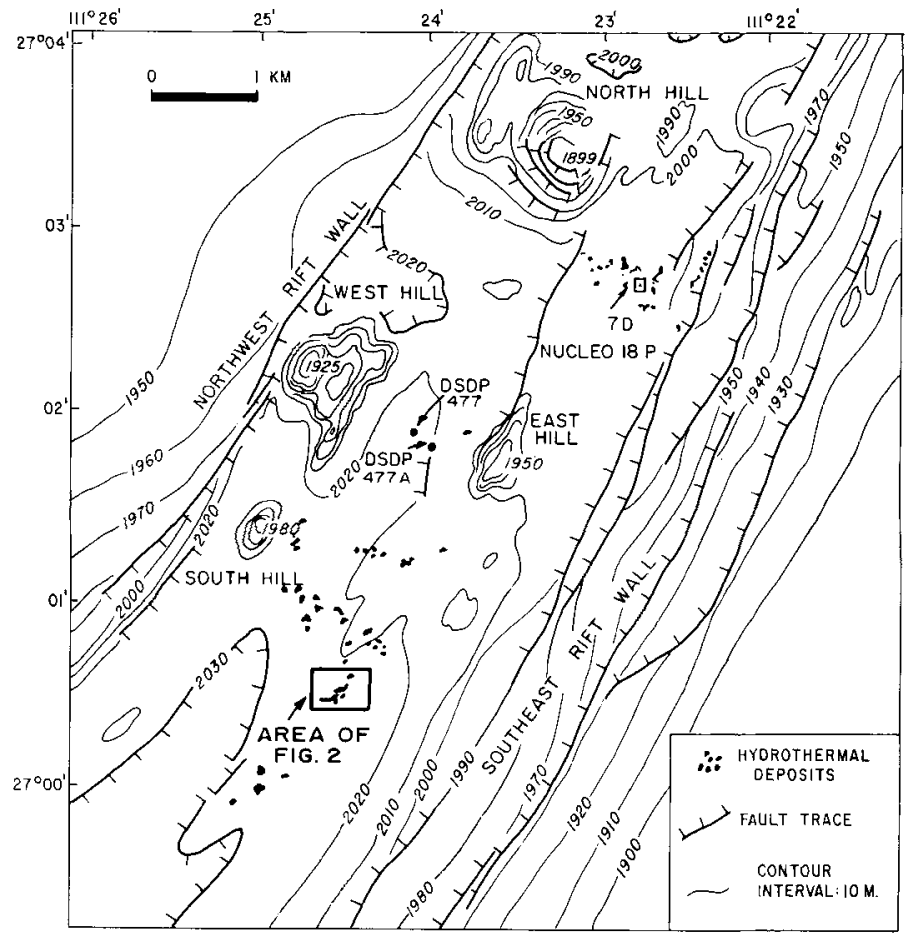

b)

Fig. 1. Area of study: (a) Guaymas Basin map showing the Northern and Southern Troughs and the hydrothermal deposits (after Lonsdale et al., 1980); (b) bathymetric and structural map of the Southern Trough showing the distribution of hydrothermal deposits (after Lonsdale \& Lawver, 1980).

The basaltic lava intrusions that form new oceanic crust in the Guaymas Basin are buried by a thick layer of hemipelagic sediments that result from a combination of high surface productivity and detrital input (Koski et al., 1985; Scientific Personnel, DSDP, leg 64, 1982). This depositional setting makes the hydrothermal vents of the Guaymas Basin different from those along other rift zones. The hydrothermal fluids flow upward through a thick later of anoxic, organic carbon-rich sediment, leaching particular chemical elements (Si, Fe, Mn, etc; Einsele et al., 1980) and producing a specific pattern of circulation (Bazylinski et al., 1988; Jones et al., 1989). Hydrothermal fluid circulation occurs off the ridge spreading axis and a patchy distribution of 'vents' or 'seeps' occurs throughout the Southern Trough. Consequently, hydrothermal mounds and 'sedimentary microfacies' are also patchy, both spatially and in faunal content (Grassle, 1985).

The composition of the biological communities in the Guaymas Basin, is also different from those found in other hydrothermal systems. The soft sediments which cover most of the basin result in steep vertical and horizontal environmental gradients, which are reflected by the macrobiota (Grassle, 1985). Thus, it is possible to relate areas with different organisms, to different environmental conditions: high sulphur concentrations, bacterial mats, 'cold seeps', etc. These aspects of the Guaymas hydrothermal area are clearly visible from a submersible. In this paper we evaluate the effect of hydrothermal activity on the microfaunal community in the Guaymas Basin.

\section{MATERIAL AND METHODS}

The sediment samples used in this investigation were collected from the Guaymas Basin, Gulf of California. Most of the samples are from the Southern Trough of the basin and were taken with the DSRV 'Alvin' in January and February 1988, in two geographical areas: 'Lutz Town' and 'Angel Rock' (Fig. 2). Additional 'control samples' (G) were taken in an area without hydrothermal influence, using the Mexican R/V 'El Puma'.

The sediments were taken with a modified $225 \mathrm{~cm}^{2} \mathrm{Ekman}$ box corer, containing four subcores $\left(56.25 \mathrm{~cm}^{2}\right)$; with plastic pipes (diameter $8 \mathrm{~cm}$ ) and with a gravity corer (diameter $13 \mathrm{~cm}$ ).

The sediment cores were subsampled on board at three levels: 'surface' $(0-5 \mathrm{~cm})$ in all localities; and 'intermediate' $(10-15 \mathrm{~cm}$ below the top of the core) and 'bottom' $(20-25 \mathrm{~cm}$ below the top of the core) in some of the localities (Table 1). It was not possible to collect samples at all three level from all localities.

The surface samples $\left(40 \mathrm{~cm}^{3}\right)$ were treated with borated-formalin, and stained with rose Bengal to 


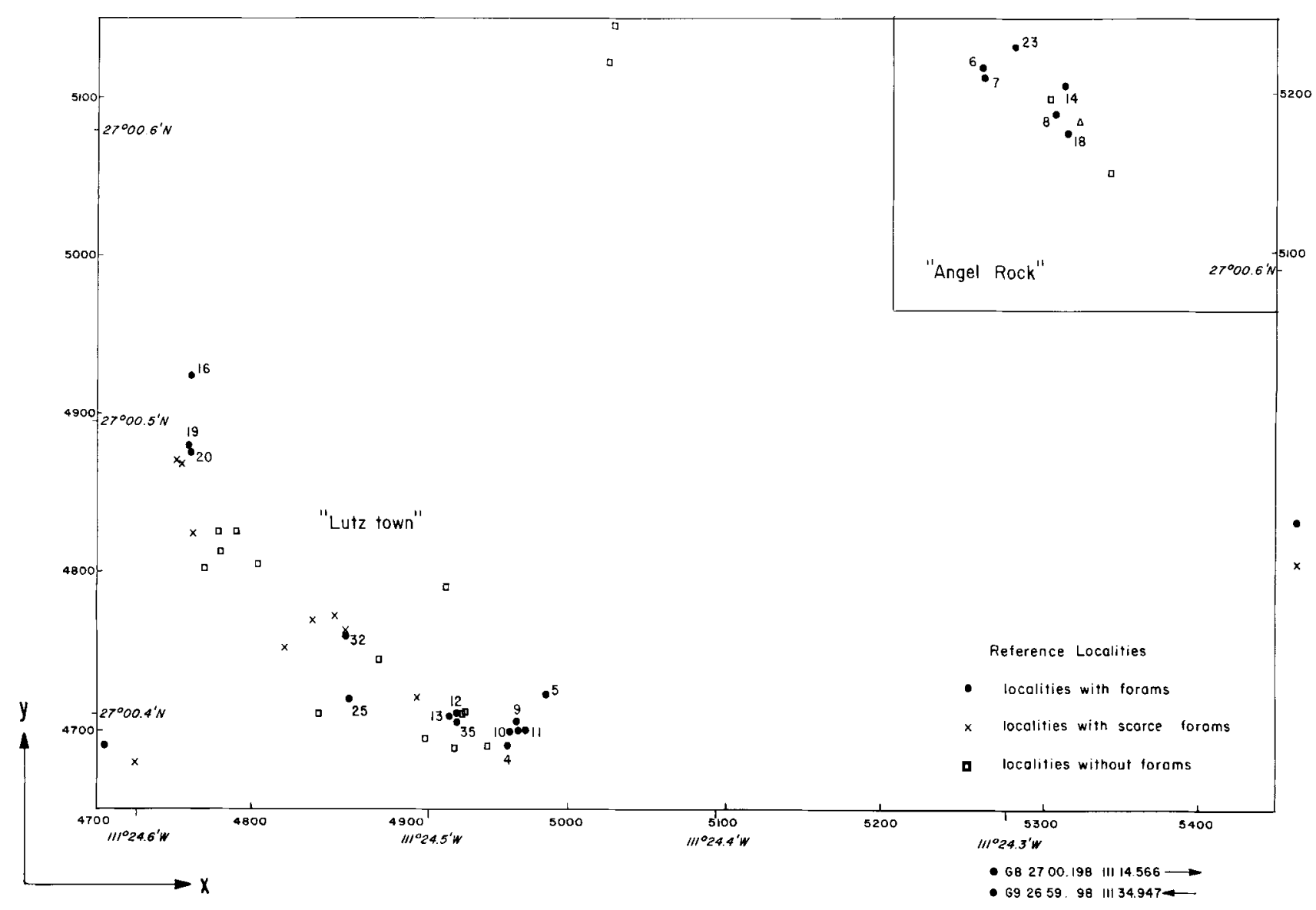

Fig. 2. Sample locations with respect to a $(x, y)$ trisponder system.

distinguish the live benthic foraminifera (Walton, 1952). In the laboratory, foraminifers, radiolarians, ostracods and diatoms were separated from the sediments by washing them through a $63 \mu \mathrm{m}$ sieve.

The abundances of different benthic foraminiferal taxa, both stained (biocoenoses) and unstained (thanatocoenoses), were determined for all samples (Table 2 and Plate 1). In addition, the total abundance (individuals per gram) of planktonic foraminifers, radiolarians (suborder Phaeodaria), and ostracod shells were estimated for each sample. The relative abundance (percentage relative to a sample of the grain population of $>62 \mu \mathrm{m}$ ) of diatoms in each sample was also estimated.

An R-mode Cluster Analysis (Buzas, 1979) of the benthic foraminiferal species abundance data (\%) both stained and unstained, was carried out to identify species of benthic foraminifera whose biocoenoses and thanatocoenoses are similar. This occurs when 'stained' variable (species) and the corresponding 'unstained' variable are associated at a 'high-level' (Table 3).

Only species which do not show significant changes in their transfer from biocoenoses to thanatocoenoses were used to carry out a Q-mode Factor Analysis (Kleinbaum et al., 1978) in order to define benthic foraminiferal assemblages and group samples (Table 4). The grouping of samples is illustrated with a 'classification triangle' (Fig. 3a; Shepard, 1954; Pettijohn, 1957), standardizing to $100 \%$ the factor loadings of the 3 factors defined in the hydrothermal region.

The factor loadings obtained in the Q-mode Factor Analysis were included as variables in a 'new' $R$-mode Cluster Analysis, to identify which benthic foraminifera species were associated with each factor (see Fig. 4).

'Biogeographical' abundance of benthic foraminifers, diatoms, radiolarians (phaeodarians), ostracods and planktonic foraminifera were also correlated with the factors, defined by the Factor Analysis, through a 'graphicmultivariate analysis' (Molina-Cruz \& Martinez-Lopez, 1994) (Figs 5 to 8), in order to make further microenvironmental inferences, as will be discussed in the results.

Figure 9 shows sketches of the distribution of 'microfacies' as seen during dives. Figures 10 and 11 represent a variant of the 'graphic-multivariate analysis': within the 'classification triangle', it is observed that a particular locality apparently shifts among environments through time. Because localities cannot move, it is inferred that this effect is rather a consequence of environmental changes, in a locality, through time, thus showing the 'environmental evolution' of particular localities. 


\begin{tabular}{|c|c|c|c|c|c|c|}
\hline & Sample & $\begin{array}{l}\text { Superficial } \\
(0-5 \mathrm{~cm})\end{array}$ & & $\begin{array}{l}\text { Intermediate } \\
(0-15 \mathrm{~cm})\end{array}$ & & $\begin{array}{c}\text { Bottom } \\
(20-25 \mathrm{~cm})\end{array}$ \\
\hline & AL-1 & 1962-A & & & & I-1 \\
\hline & AL-2 & 1962-PCX & & M-2 & & \\
\hline & $A L-3$ & $1963(7)$ & & & & \\
\hline * & $A L-4$ & $1964(2 B)$ & & M-4 & & \\
\hline$*$ & AL-5 & 1964 PC & $*$ & M-5 & $*$ & $\mathrm{I}-5$ \\
\hline * & AL-6 & 1972 B-2 & & & & \\
\hline$*$ & AL-7 & 1972 A-2 & $*$ & M-7 & & \\
\hline * & AL-8 & 1973 A-2 & $*$ & M-8 & & \\
\hline$*$ & AL-9 & 1974 B-2 & & M-9 & & \\
\hline * & AL-10 & 1974 P.L & & & & \\
\hline * & AL-11 & 1974 P.CP. & & & & \\
\hline * & AL-12 & 1975 Sales & $*$ & $M-12$ & & \\
\hline * & AL-13 & $1975 \mathrm{G}$ & & & & \\
\hline \multirow[t]{2}{*}{$*$} & AL-14 & 1976 A -2 & & M-14 & & \\
\hline & AL-15 & 1977 PC-1 & & M-15 & & $\mathrm{I}-15$ \\
\hline \multirow[t]{2}{*}{$*$} & AL-16 & 1977 PC-4 & & & & I-16 \\
\hline & AL-17 & 1978 PC-1 & & & & \\
\hline$*$ & AL-18 & 1978 A-2 & & & & \\
\hline * & AL-19 & 1979 A-2 & & & & \\
\hline \multirow[t]{3}{*}{$*$} & AL-20 & 1979 E.C. & & & & \\
\hline & AL-21 & 1977 PC-2 & & & & \\
\hline & AL-22 & 1979 PC -4 & & M-22 & & \\
\hline \multirow[t]{2}{*}{$*$} & AL-23 & 1980 A-3 & & & & \\
\hline & AL-24 & $1981 \mathrm{~N}-3$ & & & & \\
\hline \multirow[t]{3}{*}{$*$} & AL-25 & $1981 \mathrm{~N}-4$ & $*$ & $M-25$ & $*$ & $\mathrm{I}-25$ \\
\hline & AL-26 & $1981 \mathrm{~N}-1$ & & & & \\
\hline & AL-27 & 1981 4A & & & & \\
\hline \multirow[t]{4}{*}{ * } & AL-28 & $1981 \mathrm{BC} 2 \mathrm{~A}$ & & M-28 & & \\
\hline & AL-29 & 1981 PC-2 & & M-29 & & $\mathrm{I}-29$ \\
\hline & AL-30 & 1982 PC-2 & & & & \\
\hline & AL-31 & 1981 PC-1 & & M-31 & & I-31 \\
\hline \multirow[t]{3}{*}{ * } & AL-32 & 1982 BC2A & & $M-32$ & & \\
\hline & AL-33 & 1982 PC-4 & & $M-33$ & & \\
\hline & AL-34 & $19831 \mathrm{~A}$ & & M-34 & & \\
\hline \multirow[t]{2}{*}{ * } & AL-35 & $1983 \mathrm{~N}-3$ & & M-35 & & \\
\hline & AL-36 & 1983 BC4A & & $M-36$ & & \\
\hline \multirow[t]{3}{*}{ * } & AL-37 & $1984 \mathrm{~N}-4$ & & M-37 & & $\mathrm{I}-37$ \\
\hline & AL-38 & $1984 \mathrm{~N}-3$ & & M-38 & & \\
\hline & AL-39 & 1984 PC-2 & & M-39 & & I-39 \\
\hline$*$ & AL-40 & 1984 BCB & & M-40 & & \\
\hline$*$ & G-8 & GUAY-8 & $*$ & GM-8 & $*$ & GI-8 \\
\hline$*$ & G-9 & GUAY-9 & * & GM-9 & $*$ & GI-9 \\
\hline
\end{tabular}

* Employed in the mathematical analysis.

Table 1. List of samples and core level location.

\section{RESULTS AND DISCUSSION}

The results obtained from the Q-mode Factor Analysis of biocoenoses and thanatocoenoses of benthic foraminifera, indicate that four factors (assemblages) satisfactorily represent the foraminiferal community in this region (the cumulative variance is $87.6 \%$ ) (Table 4 ). Factors 1,2 and 4 represent samples from within the hydrothermal vent area, while Factor 3 contains samples from the region of Guaymas Basin that is not influenced by hydrothermal activity.

To infer the affinity between individual species and the assemblages defined by the Q-mode Factor analysis, an R-mode Cluster Analysis was carried out, using the Q-mode factor loadings also as input variables (Fig. 4). The dominant species associated with each factor are-Factor 1: Trochammina sp. and Recurvoides sp.; Factor 2: Bulimina spinosa, Bolivina seminuda, Cibicides sp. and Bolivina translucens; Factor 3: Uvigerina peregrina, Buliminella tenuata, Oridorsalis umbonatus and Oridorsalis sp.; and Factor 4: Bulimina mexicana, Globocassidulina sp. cf. C. subglobosa, Fursenkoina rotundata and Cornuspira sp.

Photographs of the major foraminiferal taxa considered in this study are shown in Plate 1. Taxonomic notes, as well as additional photographs, are found in Matoba \& Yamaguchi (1982).

In order to evaluate interrelationships among the benthic foraminiferal assemblages, a 'graphic-multivariate analysis' (Molina-Cruz \& Martinez-Lopez, 1994) was carried out on the three factors from within the hydrothermal vent area. Based on this analysis, we find that:

(1) Distinct relationships exist between each sample factor-composition and the various microenvironments described during the sampling (cool sediment, bacterial mats, and direct hydrothermal influence) (Fig. 3a) and with the two geographical areas in which the samples were collected ('Angel Rock' and 'Lutz Town') (Fig. 3b). This representation shows that each sample includes proportionately, the factors obtained through the mathematical analysis, neglecting the geographical area where they were sampled: 'Lutz Town' or 'Angel Rock'. This means that these areas do not define their own particular environment. Based on the 'microenvironments' observed during diving, we find that all samples associated with Factor 1 are from the 'bacterial mat microenvironment', the samples associated with Factor 2 belong to the 'cool microenvironment' and those associated with Factor 4 are from the 'hydrothermal microenvironment'. In the latter microenvironment, the clam Calyptogena pacifica was always present and abundant. This distinct association between benthic assemblages and microenvironments was used as a basis for further analysis.

(2) A correlation exists between each sample 'factor composition-microenvironment' and the abundance (number of individuals/gram) of benthic foraminifera, ostracods (Fig. 5), radiolaria (phaeodarians) and planktonic foraminifera (Fig. 6). The relative abundance (\%) of diatoms is also included in Fig. 6.

This analysis allows us to describe the microenvironments, considering both ecological conditions as well as preservation and/or sedimentary features. The ecological conditions should be reflected by the biogeographical distribution of the benthic communities, while preservation and/or sedimentary dynamics will control planktonic remains.

If shell abundance of benthic organisms is a function of favourable living conditions, then the low abundance of benthic foraminifera and ostracods in the 'hydrothermal microenvironment' (Fig. 5) suggests 'drastic' ecological conditions for the benthic microfauna. Such 'drastic' conditions are also indicated for the preservational aspect: since the study area is relatively small (approx $500 \mathrm{~m}^{2}$ ), it can be assumed that the planktonic input is uniform for all of the microenvironments. Since planktonic remains are relatively low in the 'hydrothermal microenvironment' (Fig. 6 ), we conclude that the high temperatures and chemistry of the hydrothermal fluid are affecting the preservation of biogenic material and limiting the establishment of the benthic population. 


\begin{tabular}{|c|c|c|}
\hline Species & Reference & Plate 1, Fig. \\
\hline 1. Ammoscalaria pseudospiralis & (Williamson), 1858: 2 , pl. 1 , figs 2,3 . & \\
\hline $\begin{array}{l}\text { 2. Bolivina seminuda } \\
\text { 3. Bolivina } \mathrm{sp} .1\end{array}$ & Cushman, 1911: 34, fig. 55 . & 4 \\
\hline 4. Bolivina subadvena & Cushman, 1926: 44, pl. 6, figs 6a,b. & \\
\hline 5. Bolivina translucens & Phleger \& Parker, 1951: 15, pl. 7, figs 13, 14a-b. & 6 \\
\hline \multicolumn{3}{|l|}{ 6. Brizalina spp. } \\
\hline 7. Bulimina mexicana & Cushman; Uchio, 1960: pl. 6, fig. 4. & 11 \\
\hline 8. Bulimina spinosa & (Heron Allen \& Earland); Bandy, 1961: 17, pl. 5, fig. 10. & 3 \\
\hline 9. Buliminella tenuata & Cushman; Uchio, 1960: pl. 6, fig. 1. & 8 \\
\hline 10. Globocassidulina sp. cf. C. subglobosa & Brady, $1881: 430$, pl. 54 , figs $17 \mathrm{a}-\mathrm{c}$. & 12 \\
\hline 11. Cassidulina subcarinata & Uchio, 1960: 68, pl. 9, figs 15,16 . & \\
\hline 12. Cibicides sp. & & 5 \\
\hline \multicolumn{2}{|l|}{ 13. Cornuspira sp. } & 14 \\
\hline 14. Epistominella smithi & (Stewart \& Stewart); Bandy, 1961: 15, pl. 5, figs 6a-c. & \\
\hline 15. Fursenkoina cornuta & (Cushman), 1913: 337, pl. 80, fig. 1. & \\
\hline 16. Fursenkoina rotundata & (Parr), 1950: 337, figs $14 a, b$. & 13 \\
\hline 17. Globobulimina affinis & (d'Orbigny), 1839: 105 , pl. 2 , figs $25-26$. & \\
\hline 18. Globobulimna pacifica & (Cushman), 1927: 67, pl. 14, fig. 12. & \\
\hline 19. Islandiella cushmani & (Stewart \& Stewart), 1930; 71 , pl. 9, fig. 5a,b. & \\
\hline 20. Lagena gracillima & (Segenza); Cushman, 1944: 21, pl. 3, fig. 3 . & \\
\hline 21. Lagena striata & (d'Orbigny), $1839: 21$, pl. 5 , fig. 12 . & \\
\hline 22. Oridorsalis $\mathrm{sp}$. & & 10 \\
\hline 23. Oridorsalis umbonatus & (Reuss), 1851: 75 , pl. 5 , figs $35 \mathrm{a}-\mathrm{c}$. & 9 \\
\hline \multicolumn{3}{|l|}{ 24. Pseudoparrella spp. } \\
\hline \multicolumn{3}{|l|}{ 25. Quinqueloculina sp. } \\
\hline 26. Recurvoides sp. & & 2 \\
\hline 27. Reophax dentaliniformis & Brady, 1881, Quarterly Journal of Microscopical Science 21: 49. & \\
\hline \multicolumn{3}{|l|}{ 28. Forma 'A' } \\
\hline \multicolumn{3}{|l|}{ 29. Forma 'D' } \\
\hline 30. Suggrunda eckisi & Natland, 1950: 23, pl. 9, figs 12a,b. & 1 \\
\hline \multicolumn{3}{|l|}{ 31. Trochammina sp. } \\
\hline 32. Uvigerina peregrina & d'Orbigny; Cushman, 1927: 157, pl. 4, fig. 1. & 7 \\
\hline 33. Valvulineria araucana & d'Orbigny; Cushman, $1927: 160$, pl. 4 , figs $7-8$. & \\
\hline
\end{tabular}

Table 2. Taxonomic framework.

The 'bacterial microenvironment' - described as Factor 1 - is intermediate, both in ecological and preservational aspects. Here, the abundance of benthic and planktonic remains is always intermediate with respect to the other two microenvironments (Figs 5 and 6). This may be due to the fact that the extreme environmental conditions associated with the hydrothermal microenvironment are diluted by mixing with the surrounding cold waters. In this region, yellow and white bacterial mats are commonly present.

According to the diving reports, the 'cool microenvironment'- described as factor 2 - is approximately $5 \mathrm{~m}$ away from direct hydrothermal influence. This microenvironment is the most favourable for the benthic foraminifera and ostracods, and also for the preservation of planktonic remains (Figs 5 and 6 , respectively). The abundance of microfossil shells was always highest in this region.

The association of several benthic foraminiferal species with each factor was enhanced through a 'graphicmultivariate analysis', contouring, within the basisclassification triangle, the relative abundance of each foraminiferal species. This analysis supports the results obtained from the mathematical analysis and led us to recognize more easily each association. For example, Trochammina sp. with Factor 1 ('Bacterial environment'); Bulimina spinosa with Factor 2 ('cool environment') and
Bulimina mexicana with Factor 4 ('Hydrothermal environment') (Fig. 7).

The poor preservation conditions observed in the 'hydrothermal microenvironment' were supported by experiments carried out in situ. Foraminifera tests and mollusc fragments were embedded in a plastic resin and then buried in sediments in each of the different microenvironment observed in the Guaymas Basin, in order to examine the dissolution effect of the hydrothermal fluids. Although the results of this experiment are rather qualitative, it is obvious that the dissolution of tests is more intense in the 'hydrothermal microenvironment' in which the clams were abundant.

In order to evaluate diversity within each of the microenvironments, the Shannon-Weiner diversity index (Krebs, 1985) was estimated for the benthic foraminifera assemblages in each sample. This analysis included 2 cases: (a) only stained data; and (b) both stained and unstained data. The mean value of diversity in each 'microenvironment' was compared with those from the area of hydrothermal influence and with the one in the area without hydrothermal influence, through a mathematical ' $f$ ' test (Remington \& Schork, 1970). Diversity between the 2 areas was significant only in the first case (stained data; hydrothermal $=0.51$; not hydrothermal $=0.28$ ). Diversity is higher in the hydrothermal region, probably as a result of 


\begin{tabular}{|c|c|}
\hline Species & $\begin{array}{c}\text { Similarity } \\
\text { index }\end{array}$ \\
\hline Ammoscalaria pseudospiralis & 0.4175 \\
\hline * Bolivina seminuda & 0.7067 \\
\hline * Bolvina sp. 1 & 0.8015 \\
\hline * Bolivina translucens & 0.7624 \\
\hline * Brizalina spp. & 0.1011 \\
\hline * Bulimina mexicana & 0.8363 \\
\hline * Bulimina spinosa & 0.874 \\
\hline * Buliminella tenuate & 0.6482 \\
\hline * Globocassidulina sp. cf. C. subglobosa & 0.6527 \\
\hline Cassidulina subcarinata & 0.3181 \\
\hline * Cibicides sp. & 0.6923 \\
\hline * Cornuspira sp. & 0.7304 \\
\hline Epistominella smithi & 0.539 \\
\hline Fursenkoina cornuta & 0.4676 \\
\hline * Fursenkoina rotundata & 0.6246 \\
\hline Globobulimina affinis & 0.1093 \\
\hline Globobulimina pacifica & 0.3656 \\
\hline Islandiella cushmani & 0.5597 \\
\hline Lagena gracillima & 0.0793 \\
\hline Lagena striata & 0.0972 \\
\hline * Oridorsalis sp. & 0.6601 \\
\hline * Oridorsalis umbonatus & 0.7385 \\
\hline Pseudoparrella spp. & 0.5903 \\
\hline Quinqueloculina sp. & 0.4184 \\
\hline * Recurvoides sp. & 0.6235 \\
\hline * Reophax denialiniformis & 0.6186 \\
\hline * Forma ' $\mathrm{A}$ ' & 0.6302 \\
\hline * Forma 'D' & 0.9058 \\
\hline * Suggrunda eckisi & 0.6157 \\
\hline * Trochammina sp. & 0.9696 \\
\hline * Uvigerina peregrina & 0.681 \\
\hline Valvulineria araucana & 0.5315 \\
\hline
\end{tabular}

Table 3. R-Mode Cluster Analysis (similarity index between stained (biocoenoses) specimens and unstained (thanatocoenoses) specimens for each species. Species which have a high level of similarity are considered 'significant' and are denoted by an asterix $\left(^{*}\right)$.

the high spatial heterogeneity observed in this area. If both the stained and unstained foraminiferal data are used in the analysis, the difference in 'diversity index' between the two areas is not significant (hydrothermal =1.01; not hydrothermal $=1.11$ ). Thus, it is suspected that detrital input can mask somewhat the ecological signals.

According to the ' $f$ ' test, the mean diversity values for the three 'microenvironments within the hydrothermal area were not significantly different. However, the 'graphicmultivariate analysis' (Fig. 8) indicates that the 'bacterial microenvironment' has the lowest diversity.

Even though the hydrothermal flux in the Guaymas Basin occurs from a large number of 'vents' or 'seeps' located randomly, it is possible to define the spatial character of the different microenvironments (Fig. 9). In the cool and hydrothermal microenvironments, the environmental conditions are more stable, with cool or hot water always present, respectively. In contrast, the bacterial mat environment is more unstable, since the temperature and water chemistry depend on the mixing of cool bottom water and hydrothermal fluids.

The above results are based on the analysis of surface samples, which are assumed to represent present-day conditions. However, how have the ecological and

\begin{tabular}{|c|c|c|c|c|}
\hline Station & Factor 1 & Factor 2 & Factor 3 & Factor 4 \\
\hline 4 & 0.32484 & 0.84507 & 0.10085 & 0.08184 \\
\hline 5 & 0.21059 & 0.95668 & -0.0558 & 0.09178 \\
\hline 6 & 0.49233 & 0.81308 & -0.09208 & 0.21235 \\
\hline 7 & -0.05531 & 0.98511 & 0.00048 & -0.0099 \\
\hline 8 & 0.42200 & 0.95168 & 0.05568 & 0.22379 \\
\hline 9 & 0.98336 & 0.10727 & -0.1136 & -0.01107 \\
\hline 10 & 0.98059 & 0.13761 & -0.09677 & 0.1568 \\
\hline 11 & 0.92766 & 0.17308 & -0.10658 & 0.22489 \\
\hline 12 & -0.05401 & 0.07417 & 0.09317 & 0.97124 \\
\hline 13 & -0.0651 & -0.04643 & 0.13400 & 0.86875 \\
\hline 14 & 0.89052 & 0.40944 & -0.10384 & 0.05199 \\
\hline 16 & 0.8335 & -0.03115 & 0.27128 & 0.0949 \\
\hline 18 & 0.96743 & 0.17632 & -0.05768 & -0.00179 \\
\hline 19 & 0.4441 & 0.54805 & -0.2286 & -0.02813 \\
\hline 20 & 0.32177 & 0.92893 & -0.05953 & -0.06685 \\
\hline 23 & 0.97986 & 0.09959 & -0.12433 & 0.06635 \\
\hline 25 & 0.23215 & 0.82782 & 0.38279 & 0.2259 \\
\hline 27 & 0.34998 & 0.26263 & -0.07578 & 0.55743 \\
\hline 28 & 0.60434 & 0.08364 & 0.13646 & 0.5677 \\
\hline 32 & 0.00392 & -0.10919 & 0.17613 & 0.8475 \\
\hline 35 & 0.66071 & 0.10867 & 0.36312 & 0.47653 \\
\hline 37 & 0.02428 & 0.99197 & 0.00267 & -0.01943 \\
\hline 40 & 0.18688 & 0.58717 & -0.10868 & 0.046643 \\
\hline M5 & 0.10681 & 0.95509 & 0.06793 & -0.13824 \\
\hline M7 & 0.95781 & 0.22855 & 0.11754 & -0.03753 \\
\hline M8 & 0.98556 & -0.01497 & 0.08909 & 0.05391 \\
\hline M12 & 0.74556 & -0.14889 & 0.51332 & 0.23500 \\
\hline M25 & 0.8061 & 0.40902 & -0.03025 & -0.20805 \\
\hline 15 & 0.0244 & 0.95082 & 0.02892 & -0.17368 \\
\hline $\mathrm{I} 25$ & 0.89887 & 0.40289 & -0.0484 & -0.08822 \\
\hline G8 & -0.00638 & 0.14468 & 0.77687 & 0.32814 \\
\hline G8 & -0.9673 & 0.15976 & 0.80706 & 0.13704 \\
\hline GM8 & 0.12387 & 0.3005 & 0.9148 & 0.04314 \\
\hline GM9 & -0.02871 & -0.14200 & 0.88928 & -0.00141 \\
\hline GI8 & 0.00269 & -0.13218 & 0.95592 & 0.02652 \\
\hline GI9 & 0.00517 & -0.12878 & 0.93479 & -0.02542 \\
\hline
\end{tabular}

Cummulative variance was 87.6

Table 4. Q-mode Varimax Matrix. Samples preceded by ' $M$ ' represent intermediate core levels, samples preceded by 'I' represent bottom core levels and samples preceded by a ' $G$ ' represent samples from Guaymas Basin without the hydrothermal influence.

sedimentary conditions in this hydrothermal region changed with time? To answer this question we analysed subsurface samples from two depths $(10-15 \mathrm{~cm}$ and $20-25 \mathrm{~cm})$ at some of the surface sample localities. The benthic foraminiferal data for the intermediate $(10-15 \mathrm{~cm})$ and bottom $(20-$ $25 \mathrm{~cm}$ ) subsamples and the resultant factors obtained by Q-mode Factor Analysis are given in Table 4. All sub-bottom samples from the region of the Guaymas Basin without any hydrothermal influence are associated with Factor 3.

A 'graphic-multivariate analysis' of the sub-bottom samples was carried out in order to examine changes in the fauna and associated environmental conditions through time (Fig. 10). At sample localities 7, 8 and 25 the sub-bottom fauna indicates that a 'bacterial microenvironment' existed in the past, while these locations are at present within the 'cool microenvironment'. This suggests changes in the dynamics of the hydrothermal regime through time. At locality 12 , there has been a change from a bacterial 

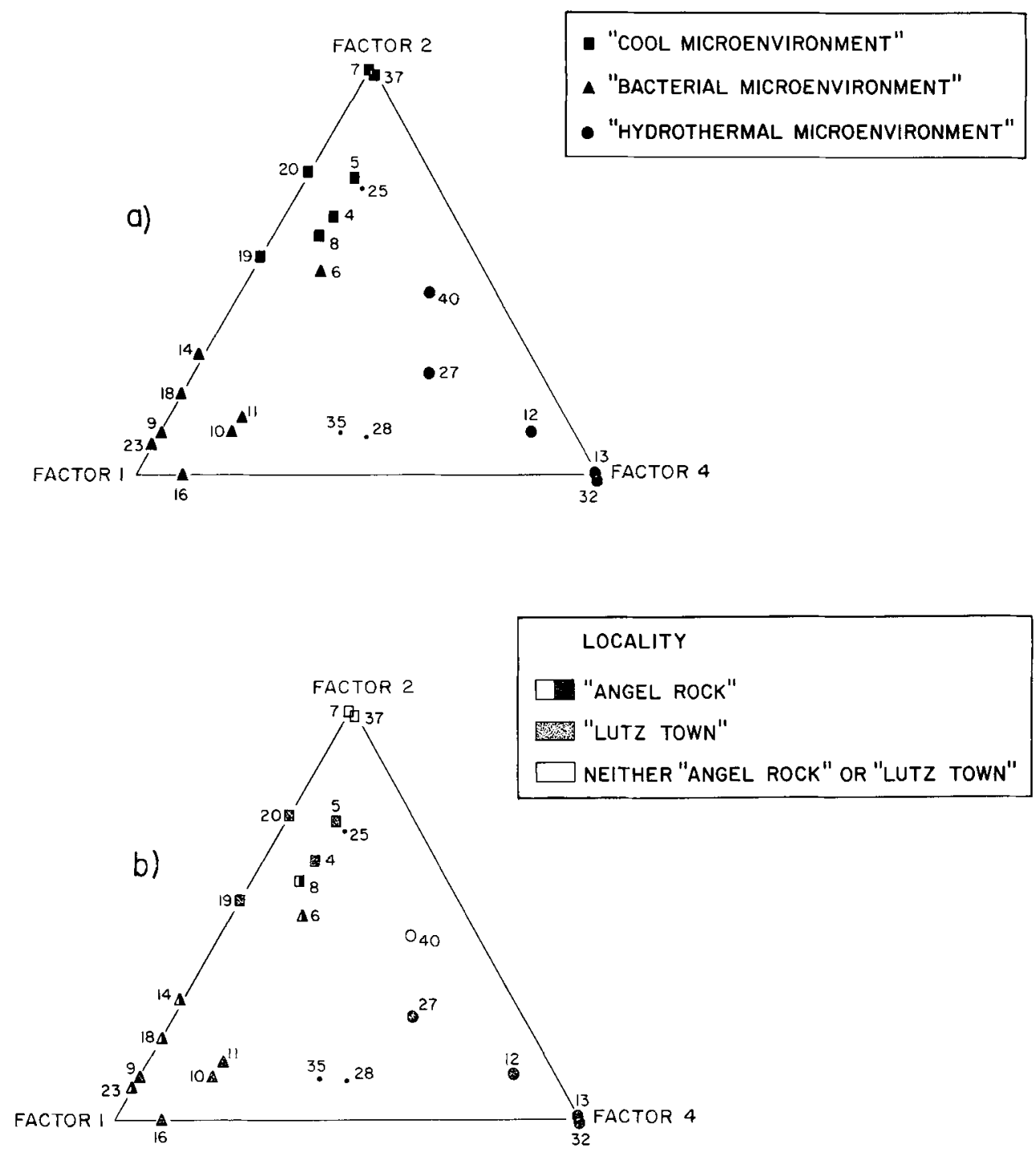

Fig. 3. Relation of sample Factor-composition with: (a) 'visual microenvironment'; (b) the same, but considering geographic position - Lutz Town or Angel Rock.

microenvironment' to the present 'hydrothermal' environment; thus, suggesting that the hydrothermal flux at this site was lower in the past or that hydrothermal activity was recently established near this site. The fauna at site 5 indicates no changes in environmental conditions with time. Due to a lack of stratigraphic control, it was not possible to correlate the sub-bottom samples between cores.

The abundances of benthic foraminifera, radiolaria, planktonic foraminifera, ostracods, and diatoms in the sub-bottom samples were analysed with a variant of the 'graphic-multivariate analysis'. This analysis determines whether the increase (or decrease) of the abundances of these groups is coherent or not, with the 'microenvironment' changes, through time, at each locality. The relationship established between abundance-microenvironment for the surface samples (Figs 5 and 6), is consequently considered in this analysis (Fig. 11).
For benthic foraminifera (Fig. 11a), there is a general tendency for abundance to increase with a change from the bacterial microenvironment to the cool environment; thus supporting our conclusion that the less severe environmental conditions result in better colonization and/or preservation of tests. For example, at locality 12 a decrease in benthic foraminiferal abundance suggests an increase in hydrothermal influence with time.

For radiolaria (phaeodarians) (Fig. 11c), there is also a tendency for the number of specimens to increase as the depositional environment becomes cooler. The planktonic foraminfers (Fig. 11d), show a similar pattern of increase in number with less hydrothermal influence. The diatoms and ostracod abundance (Figs 11e and 11b) show no clear pattern.

Consequently, the microfaunal analysis of the sub-bottom samples supports the results obtained from the surface 


\section{RESCALED DISTANCE CLUSTER COMBINE}

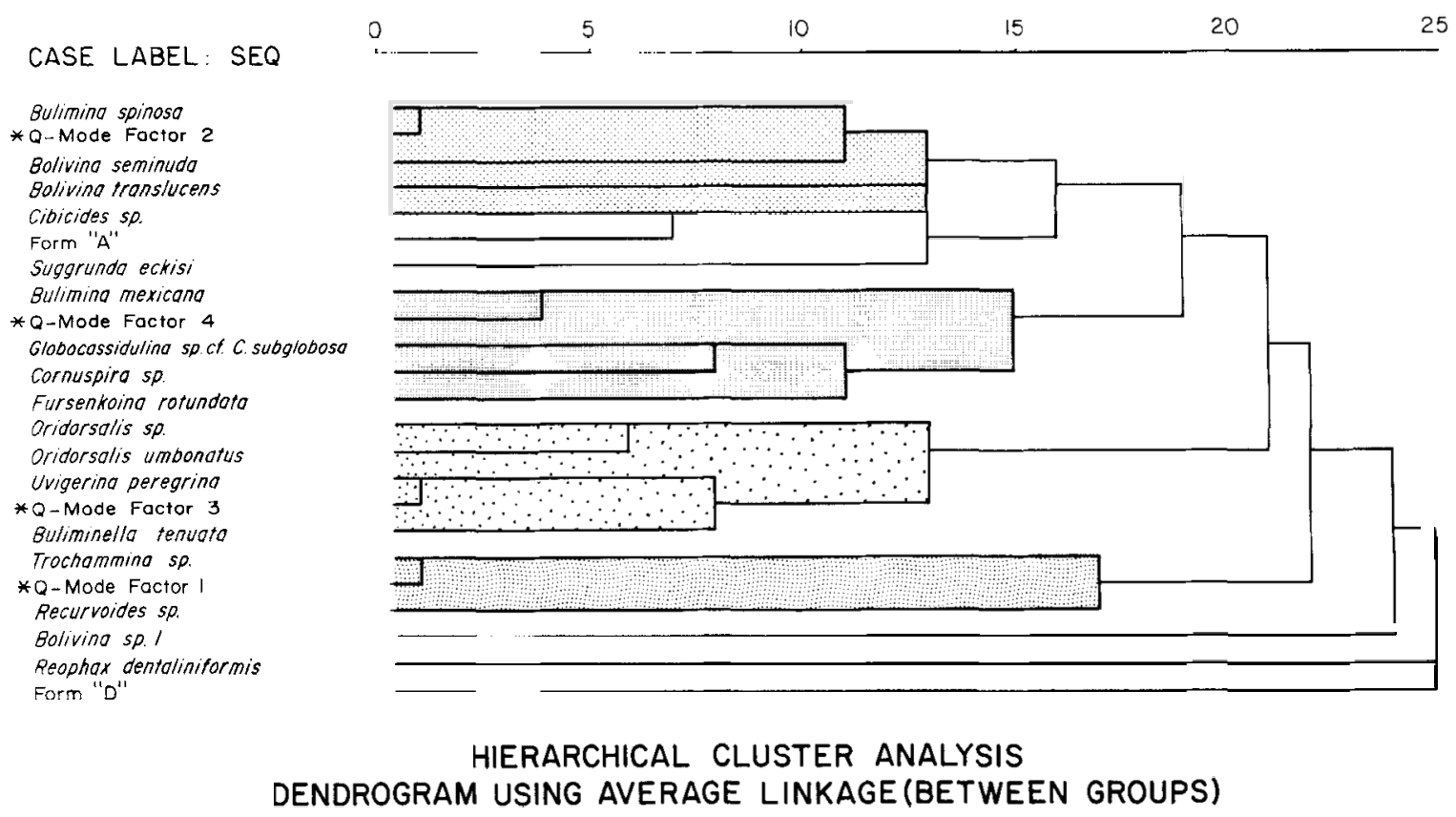

Fig. 4. Dendrogram of an R-mode Factor Analysis, in which the Q-mode Factor Analysis loading were input also as variables (sec text).
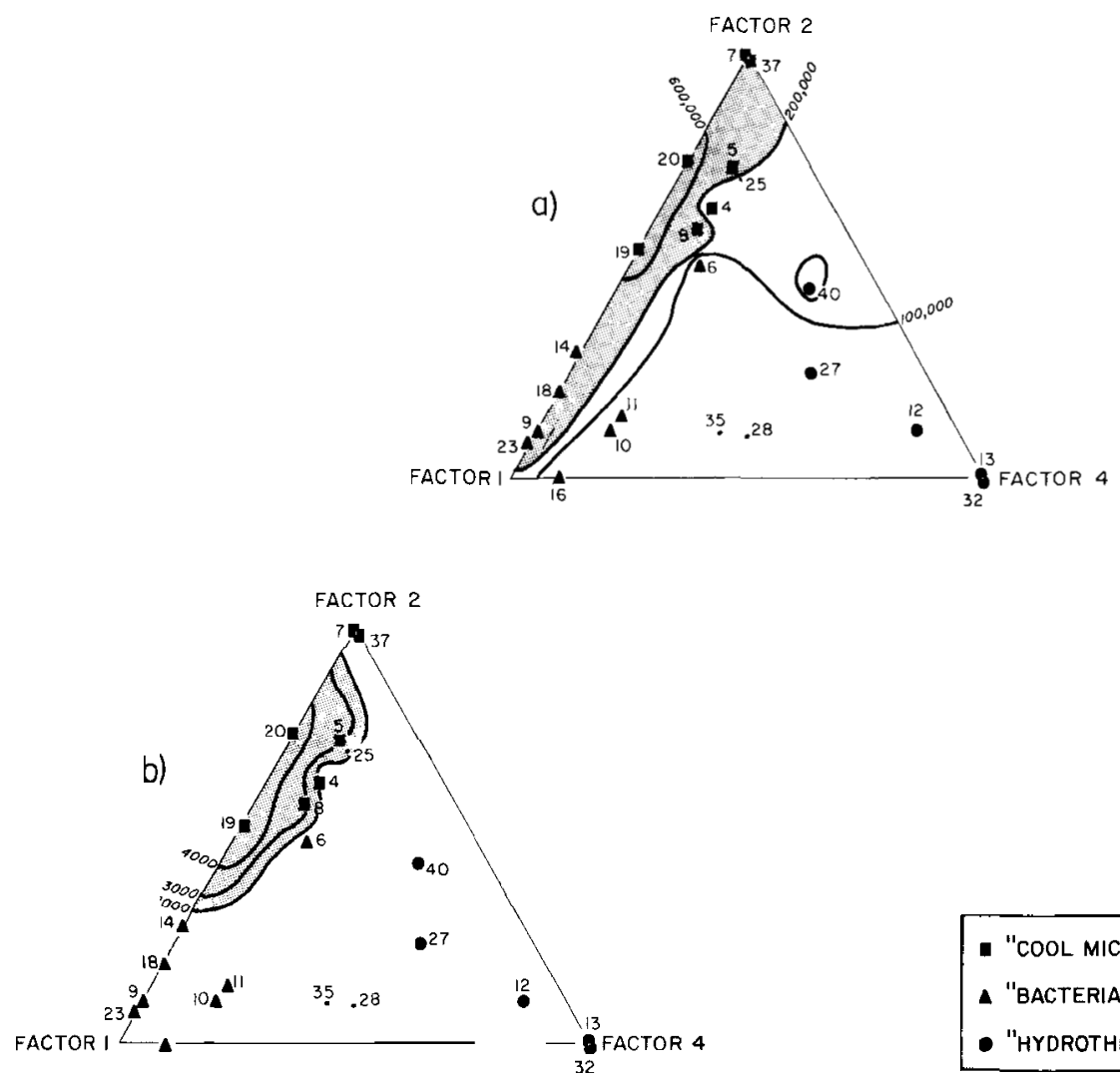

- "COOL Microenvironment"

ـ "Bacterial microenvironment"

- "HYDROTHERMAL MICROENVIRONMENT"

Fig. 5. Relationship of sample factor-composition and 'visual microenvironment' with relative abundance of: (a) benthic foraminifera; and (b) ostracods. The contours refer to individuals per gram. 

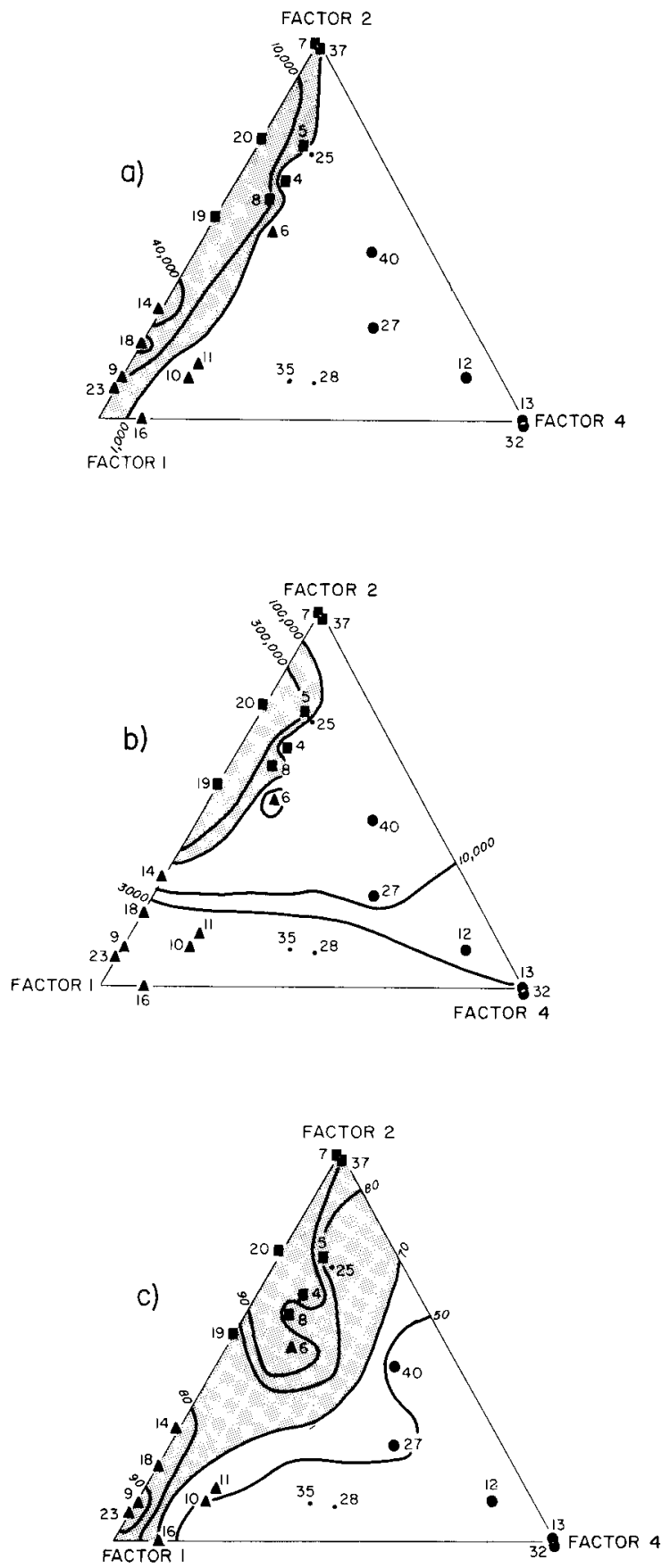

- "COOL MICROENVIRONMENT"

4 "BACTERIAL MICROENVIRONMENT"

- "hYDROTHERMAL MicroenVIRONMENT"

Fig. 6. Relationship of sample factor-composition and 'visual microenvironment' with relative abundance of: (a) radiolaria; (b) planktonic foraminifera; and (c) diatoms. The contours refer to individuals per gram in (a) and (b); for (c), these refer to percentages, relative to the micropalaeontological population.
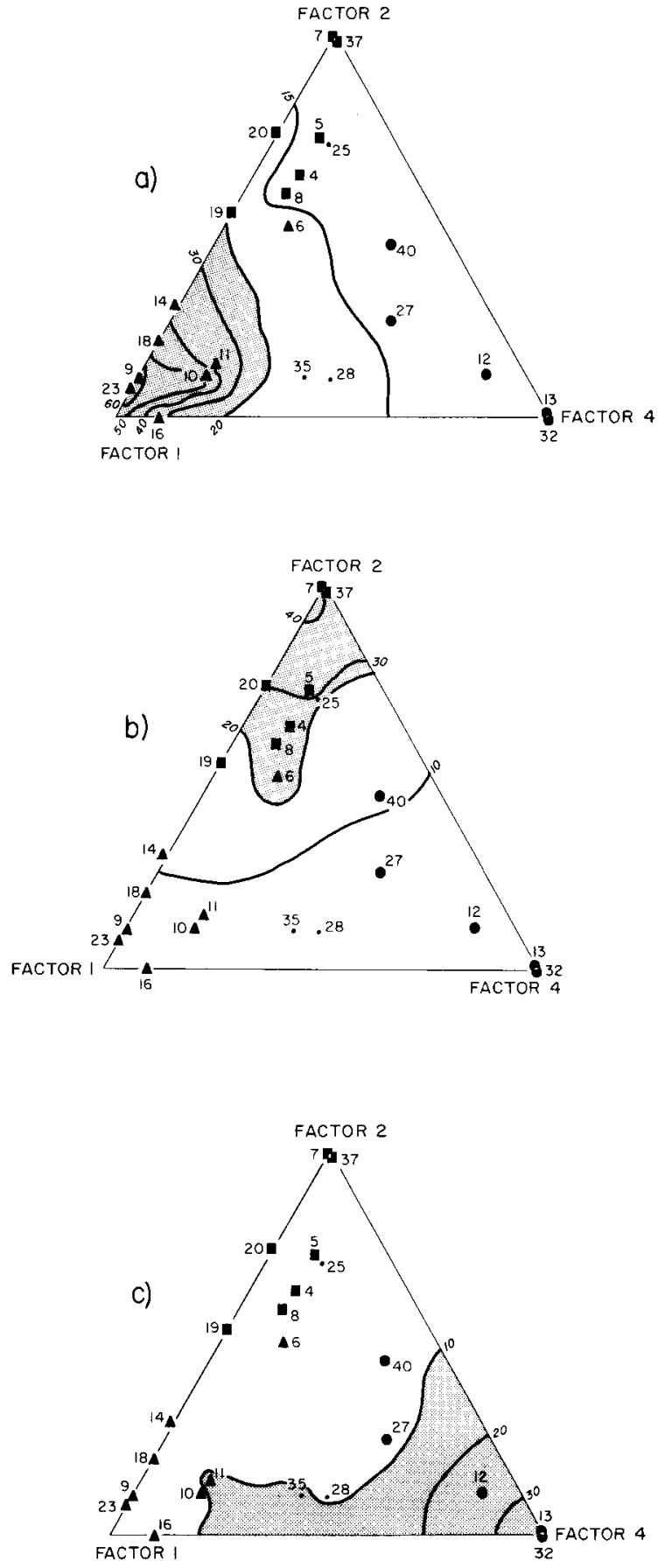

- "COOL MICROENVIRONMENT"

4 "BACTERIAL MICROENVIRONMENT"

- "HYDROTHERMAL MICROENVIRONMENT"

Fig. 7. Relationship of sample factor-composition and 'microenvironment' with relative abundance of: (a) Trochammina sp.; (b) Bolivina spinosa; and (c) Bulimina mexicana. The contours refer to percentages, relative to the foraminifera population. 


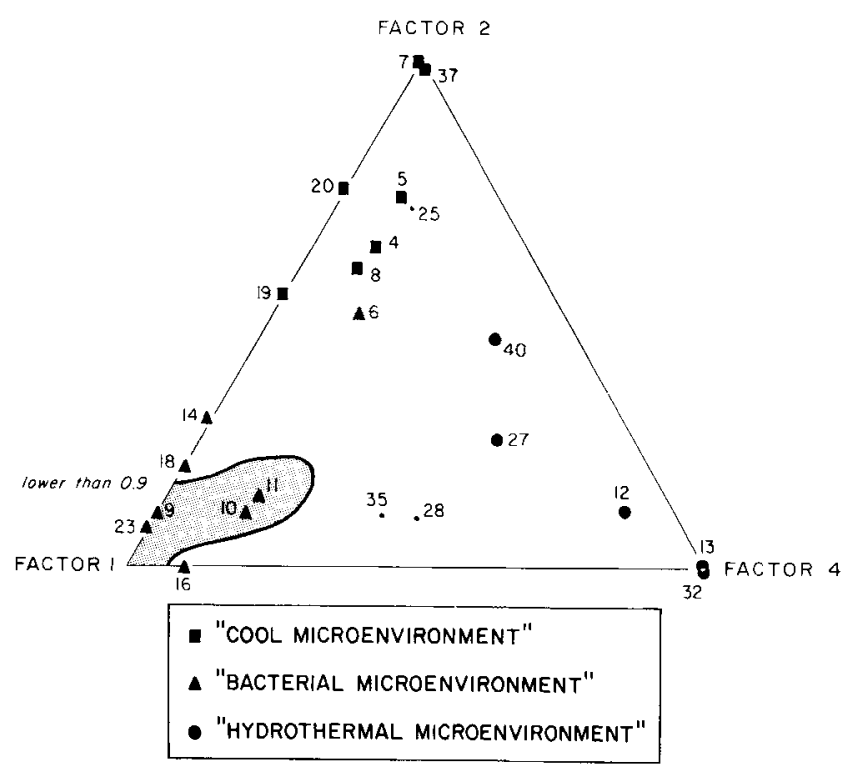

Fig. 8. Relationship of sample factor-composition and 'microenvironment' with diversity values (Shannon-Weiner index). The contour refers to diversity values (see text).
HYDROTHERMALVENT

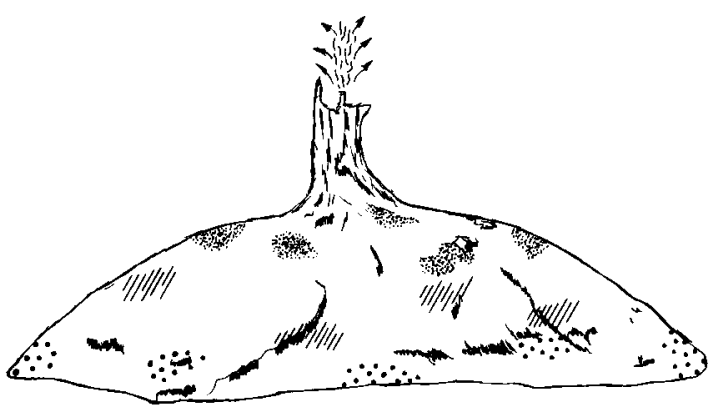

HYDROTHERMALFLUIDS

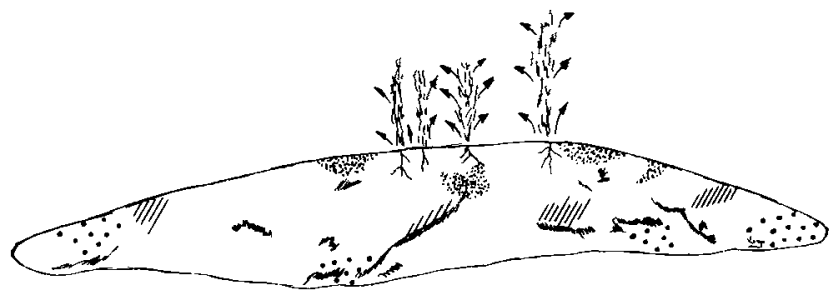

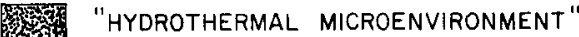

VIIIIA "BACTERIAL MICROENVIRONMENT"

$\because \because$ "COOL MICROENVIRONMENT"

Fig. 9. Sketch of disposition of the different microenvironments around the hydrothermal fluid (see text).

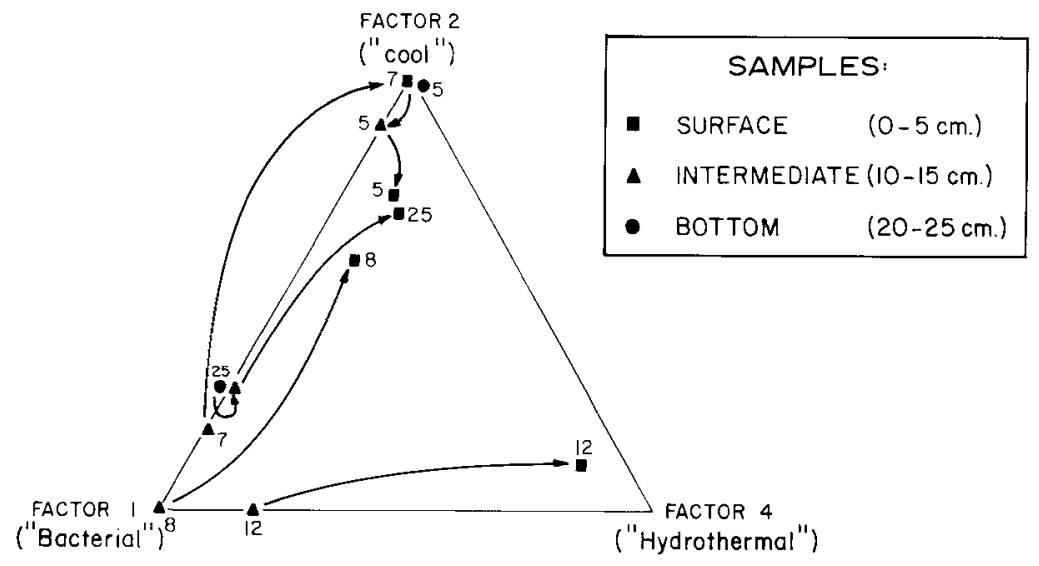

Fig. 10. Relationship of surface sample factor-composition and 'microenvironment' with sub-bottom samples. The arrows indicate chronological shifting, the tail of the arrow the oldest position. 
The Hydrothermal Region, Guaymas Basin, Mexico
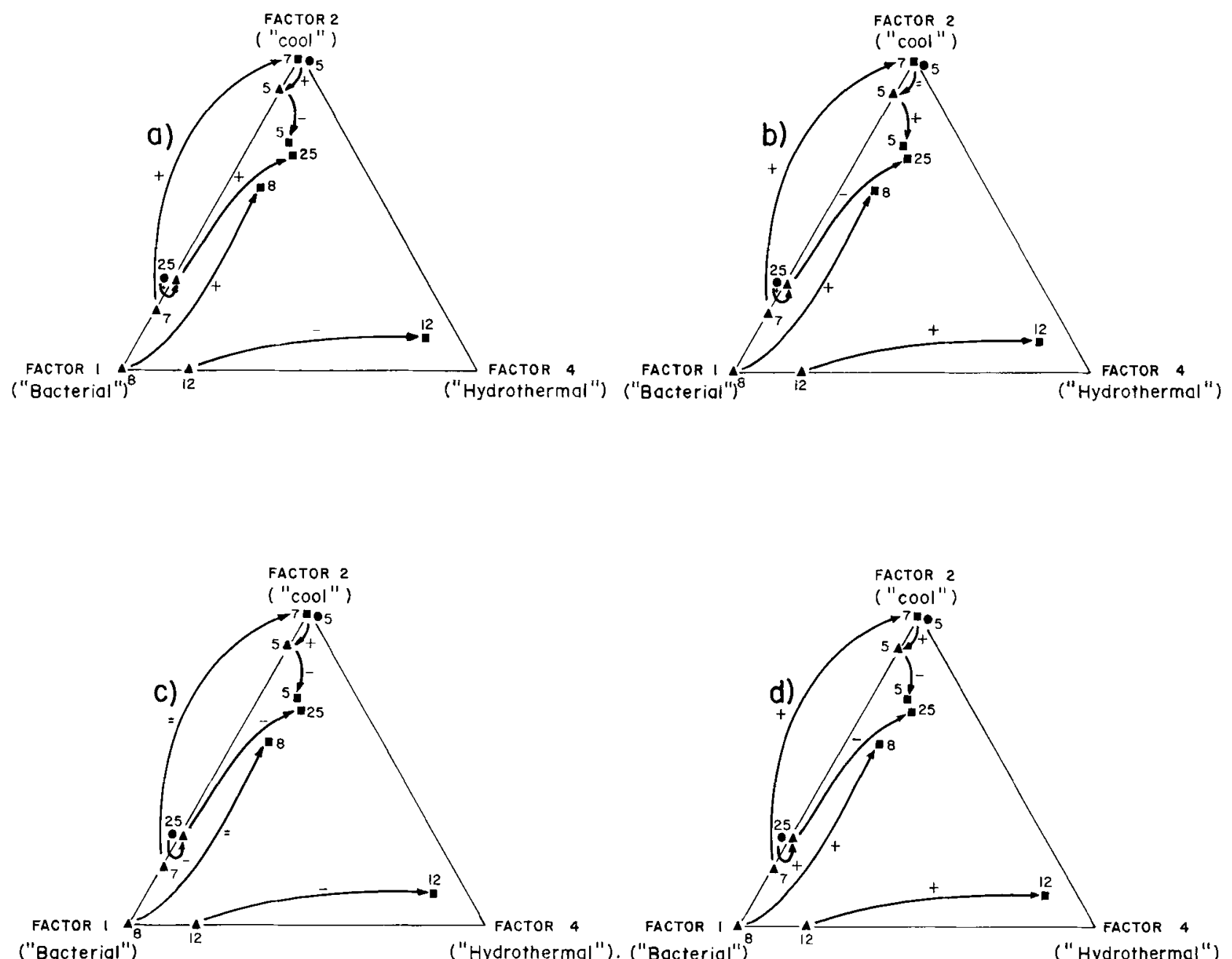

("Bacterial")

("Hydrothermal"). ("Bacterial")

("Hydrotherma")
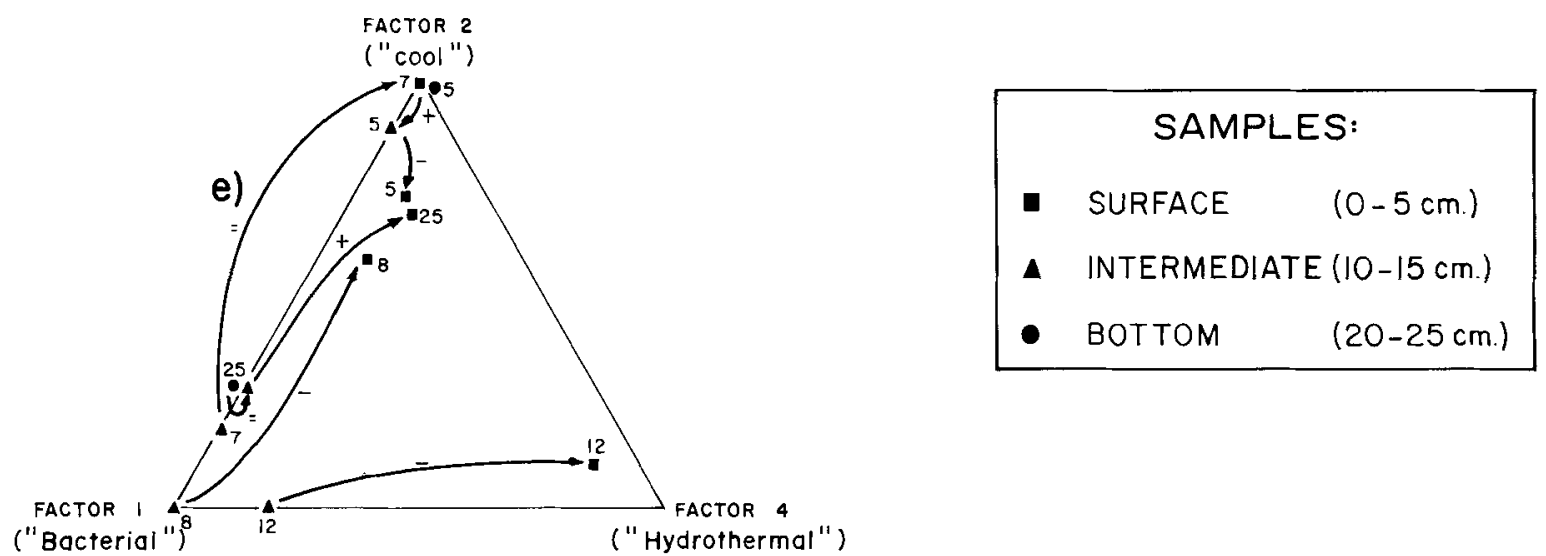

Fig. 11. Relationship of surface sample factor-composition and 'microenvironment' with sub-bottom samples. In this analysis the symbols + or - denote increase or decrease in abundances through time, respectively (see Fig. 10). The cases are: (a) for benthic foraminifera; (b) for radiolarians; (c) for diatoms; (d) for planktonic foraminifera; and (e) for ostracods. 
samples. The more severe conditions associated with the hydrothermal environment result in poor survival and preservation of microorganisms. The 'bacterial microenvironment' is relatively unstable in comparison to the other two 'microenvironments' because it is a region of mixing of cold bottom water and hydrothermal fluids. This makes the faunal populations very sensitive to environmental changes. The greatest abundance of microfaunal remains is always associated with the 'cool microenvironment'.

This study represents a contribution to the general understanding of biotic response to hydrothermal vent systems. Through the analysis of benthic microfaunal communities and planktonic thanatocoenoses, we can identify faunal-microenvironmental relationships. A better understanding of depositional rates in the basin would allow us to reconstruct spatial changes in the various hydrothermal microenvironments through time.

\section{CONCLUSIONS}

Four microenvironments are present in the study region of Guaymas Basin: three are associated with hydrothermal activity: (a) the 'hydrothermal'; (b) the 'bacterial'; and (c) the 'cool'. The fourth microenvironment is out of the hydrothermal influence: the 'Guaymas Basin'.

A 'graphic-multivariate analysis' was used to correlate the Factor Analysis results with the 'biogeography' of diatoms, radiolarians, planktonic foraminifers and ostracods. This provided a better understanding of the ecological and sedimentary environments in the region.

(a) In the 'hydrothermal microenvironment' (Factor 4), the direct influence of the hydrothermal fluid reduces drastically the occurrence of microfossils. Preservation of planktonic thanatocoenoses is very poor in this environment. However, the benthic foraminifera Bulimina mexicana and Globocassidulina sp. cf. $C$. subglobosa are able to live together with the mollusc Calyptogena pacifica.

(b) The 'bacterial microenvironment' (Factor 1), in which Trochammina sp. and Recurvoides sp. are characteristic, represents the mixing of bottom water and hydrothermal fluids. Therefore, it is a relatively unstable microenvironment and transitional between the cool and hydrothermal environments.

(c) The 'cool microenvironment' (Factor 2), more removed from direct hydothermal influence, is the best for the survival of benthic forms (foraminifera and ostracods) and for the preservation of planktonic remains. Bulimina spinosa, Bolivina seminuda and Cibicides sp. are common in this microenvironment.

All three of these benthic foraminiferal assemblages differ from that found in the region of the Guaymas Basin (Factor
3), without any hydrothermal influence. Uvigerina peregrina and Buliminella tenuata are the important species in Factor 3. This assemblage is different in diversity from those of the hydrothermal area. In the Guaymas Basin samples without hydrothermal influence, diversity is lower than in the samples from the hydrothermal area. This can be explained by the fact that the hydrothermal area has more spatial heterogeneity.

Analysis of sub-bottom samples shows the same relationships as in the surface samples. The most severe environmental conditions (i.e. the hydrothermal microenvironment) result in lower survival and poor preservation of the microfauna. The 'bacterial' and the 'cool' microenvironments are characterized by higher numbers of benthic fauna and better preservation of plankton shells. The analysis of the sub-bottom samples allowed us to infer changes in the hydrothermal influence and environmental conditions with time.

\section{ACKNOWLEDGEMENTS}

This study was carried out as part of the Project 'PROGEMA' and has been supported by the National University of Mexico (UNAM) through its Direction of Academic Affairs (DGAPA). We thank sincerely Drs R. Lutz and F. Grassle for the opportunity of diving in the DSRV Alvin, as well as to Dr R. Thunnell for reading this manuscript. This is extended to Ms Yolanda Hornelas for the electron-microscopic photographs and to Mr Fernando Vega for the drawings.

\section{Manuscript received September 1992 Manuscript accepted January 1994}

\section{REFERENCES}

Ballard, R. D. 1984. The Exploits of Alvin and Angus: Exploring the East Pacific Rise. Oceanus, 27(3): 7-14.

Bandy, O. L. 1961. Distribution of foraminifera, radiolaria and diatoms in sediments of the Gulf of California. Micropaleontology, 7(1): 1-26.

Bazylinski, D. A., Farrington, J. W. \& Jannasch, H. W. 1988. Hidrocarbons in surface sediments from a Guaymas Basin hydrothermal vent site. Organic Geochemistry, 12(6): 547-558.

Brady, H. B. 1881. Notes on some of the reticularian Rhizopoda of the Challenger expedition: Part III. Quarterly Journal of Microscopical Science, 21: 31-71.

Buzas, M. A. 1979. Quantitative Biofacies Analysis. In Lipps, J. H., Buzas, M. A., Douglas, R. C. \& Ross, C. A. (Eds), Foraminiferal Ecology and Paleoecology, 11-20, SEPM Short Course, 6, USA.

Campbell, A. C. \& Gieskes, J. M. 1984. Water column anomalies associated with hydrothermal activity in the Guaymas Basin, Gulf of California. Earth and Planetary Science Letters, 68: 57-72.

Cushman J. A. 1911. A monograph of the foraminifera of the North Pacific Ocean: Part 2, Textulariidae. US National Museum Bulletin, 71: 1-108.

\section{Explanation of Plate 1}

SEM micrographs: Fig. 1. Trochammina sp. $(\times 361)$. Fig. 2. Recurvoides sp. $(\times 121)$. Fig. 3. Bulimina spinosa $(\times 401)$. Fig. 4. Bolivina seminuda $(\times 361)$. Fig. 5. Cibicides sp. $(\times 541)$. Fig. 6. Bolivina translucens $(\times 301)$. Fig. 7. Uvigerina peregrina $(\times 151)$. Fig. 8. Buliminella tenuata $(\times 401)$. Fig. 9. Oridorslis umbonatus $(\times 161)$. Fig. 10. Oridorsalis sp. $(\times 241)$. Fig. 11. Bulimina mexicana $(\times 261)$. Fig. 12. Globocassidulina sp. cf. C. subglobosa $(\times 441)$. Fig. 13. Fursenkoina rotundata $(\times 201)$. Fig. 14. Cornuspira sp. $(\times 201)$. Fig. 15. Planktonic foraminifera $(\times 181)$. Fig. 16. Radiolaria (phaeodaria) $(\times 241)$. Fig. 17. Ostracod $(\times 181)$. 


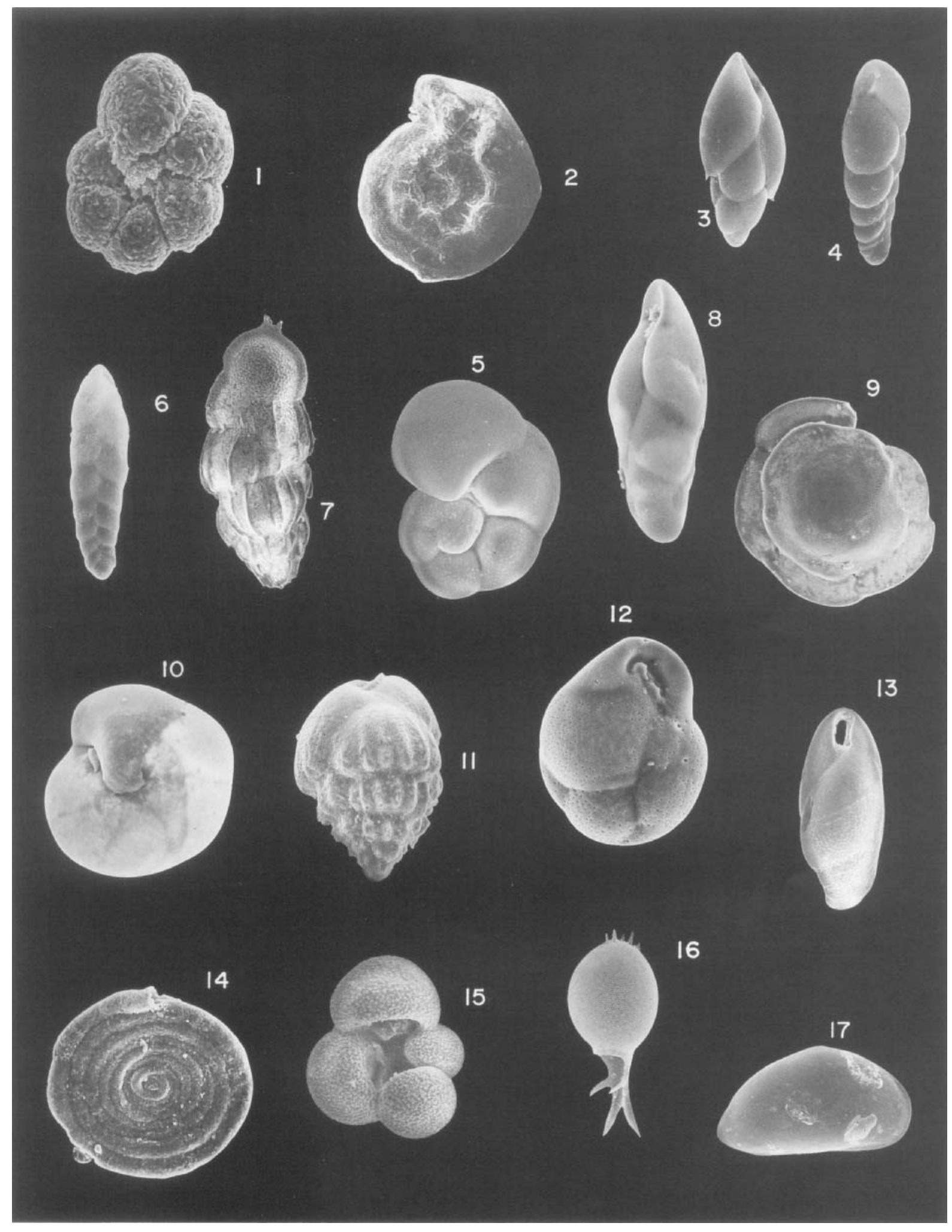

Plate 1. 
Cushman, J. A. 1913. New Textulariidae and other arenaceous foraminifera form the Philippine Islands and contiguous waters. Proceedings of the US National Museum, 44: 633-638.

Cushman, J. A. 1926. Some Pliocene Bolivinas from California. Contributions from the Cushman Laboratory for Foraminiferal Research, 1: 29-35.

Cushman, J. A. 1927. An outline of a re-classification of the foraminifera. Contributions from the Cushman Laboratory for Foraminiferal Research, 3: 1-105.

Cushman, J. A. 1944. Foraminifera from the Shallow Water of the New England Coast. Cushman Laboratory for Foraminiferal Research, Special Publication no. 12.

d'Orbigny, A. D. 1839. Voyage dans l'Amerique MeridionaleForaminiferes, 5: V. Levrault, Strasbourg.

Edmond, J. M. 1984. Marine geochemists are gaining new insight into how ore is formed. Oceanus, 27(3): 15-20.

Einsele, G., Gieskes, J. M., Curray, J., Moore, D. M., Aguayo, E., Aubry, M. P., Fornari, D., Guerrero, J., Kastner, M., Kelts, K., Lyle, M., Matoba, Y., Molina-Cruz, A., Niemitz, J., Rueda, J., Saunders, A., Schrader, H., Sinomeit, B. \& Vacquier, V. 1980. Intrusion of basaltic sills into highly porous sediments, and resulting hydrothermal activity. Nature, 283: 441-445.

Gieskes, J., Kastner, M., Einsele, G., Kelts, K. \& Niemitz, J. 1982. Hydrothermal activity in the Guaymas Basin, Gulf of California: a synthesis. In Blakeslee, J., Platt, L. W. \& Stout, L. (Eds), Initial Reports of the Deep Sea Drilling Project, 64: 1169-1178. US Government Printing Office, USA.

Grassle, J. F. 1984. Animals in the soft sediments near hydrothermal vents. Oceanus, 27(3): 63-66.

Grassle, J. F. 1985. Hydrothermal vent animals: distribution and biology. Science, 229: 713-717.

Jones, W. J., Stugard, C. E. \& Jannasch, H. W. 1989. Comparison of thermofilic methanogens from submarine hydrothermal vents. Archives of Microbiology, 151: 314-318.

Kim, J. O. 1979 Factor Analysis. In Nie, N. et al. (Eds), Statistical Package for the Social Science, 468-514, USA.

Kleinbaum, D. G., Kupper, L. L. \& Keith, M. 1978. Applied regression analysis and other multivariable methods. Puls-Kent Publishing Co., USA.

Koski, R. A., Lonsdale, P. F., Shanks, W. C., Berndt, M. E. \& Howe, S. S. 1985. Mineralogy and Geochemistry of a Sediment-Hosted Hydrothermal Sulfide Deposit from the Southern Trough of Guaymas Basin, Gulf of California. Journal of Geophysical Research, 90(b8): 6695-6707.

Krebs, C. I. 1985. Ecologia: Estudio de la distribucion y la abundancia. Cap. 23: Diversidad de Especies. Ed. Harla, Mexico, p. 495-536.

Lonsdale, P. F., Bischoff, J. L., Burns, U. M., Kastner, M. \& Sweeney, R. E. 1980. A high temperature hydrothermal deposits on the seabed at the Gulf of California Spreading Center. Earth and Planetary Science Letters, 49: 8-20.

Lonsdale, P. F. \& Lawver, L. A. 1980 . In mature plate boundary zones studied with a submersible in the Gulf of California.
Geological Society of America Bulletin, 91: 555-569.

Matoba, Y. \& Yamaguchi, A. 1982. Late Pliocene to Holocene Benthic Foraminifera of the Guaymas Basin, Gulf of California: sites 477 through 481 . In Curray, J. R., Moore, D. G. et al. (Eds), Initial Reports of the Deep Sea Drilling Project, 64: 1027-1056. US Government Printing Office, USA.

Molina-Cruz, A. \& Ayala-Lopez, A. 1988. The influence of hydrothermal vents on the distribution of benthic foraminifera from the Guaymas Basin, Mexico. Geo-Marine Letters, 8: 49-56.

Molina-Cruz, A. \& Martinez-Lopez, M. 1994. Oceanography of the gulf of Tehuantepec, Mexico, indicated by Radiolaria remains. Palaeogeography, Palaeoclimatology and Palaeocology, 110: 18-35.

Natland, M. L. 1950. Report of the Pleistocene and Pliocene foraminifera. 1940 E. W. Scripps Cruise to the Gulf of California, Part 4. Geological Society of America Memoir, 43: 1-55.

Parr, W. J. 1950. Foraminifera. BANZARE Reports $B, 5(\mathrm{pt6})$ : 233-392.

Pettijohn, F. J. 1957. Sedimentary Rocks. Ed Harper and Brothers, USA.

Phleger, F. B. \& Parker, F. L. 1951. Ecology of foraminifera of northwest Gulf of Mexico. Geological Society of America Memoir, 46(2): 159-184.

Rau, G. H. 1985. C/C and N/N in hydrothermal vent organisms: Ecological and biogeochemical implications. In Jones, M. L. (Ed.) Hydothermal Vents of the Eastern Pacific. An Overview. Bulletin of the Biological Society Washington, 6: 243-247.

Remington, R. D. \& Schork, M. A. 1970. Statistics with applications to the Biological and Health Sciences. Chapter 11: Analysis of variance. Prentice Hall, Inc., USA, 282-288.

Reuss, A. F. 1851. Die Foraminiferen und Entomostrateen des Kreidemergels von Lemburg-Haidingers Naturwissenschaftliche Abhandlungen, 4: 17-52, pls 2-6.

Scientific Personnel, DSDP, LEG 64. 1982. In Curray, J. R. Moore, D. G. et al. (Eds), Initial Reports of the Deep Sea Drilling Project, 64. US Government Printing Office USA.

Shepard, F. P. 1954. Nomenclature based on sand-silt-clay ratios. Journal of Sedimentary Petrology, 24; 151-158.

Simoneit, B. R. T. \& Lonsdale, P. F. 1982, Hydrothermal Petroleum in Mineralized Mounds at the seabed of Guaymas Basin. Nature, 295: 198-202.

Stewart, R. E. \& Stewart, K. C. 1930. Post-Miocene foraminifera from the Ventura Quadrangle, Ventura County, California. Journal of Paleontology, 4: 60-72.

Uchio, H. 1960. Ecology of living benthonic foraminifera from the San Diego, California area. Cushman Foundation for Foraminiferal Research Special Publication, 5: 1-72.

Walton, W. R. 1952. Ecology of living benthonic foraminifrera, Todos Santos Bay, Baja California. Journal of Paleontology, 29: 952-1018.

Williamson, W. C. 1858. On the Recent Foraminifera of Great Britain, Ray Society, London. 